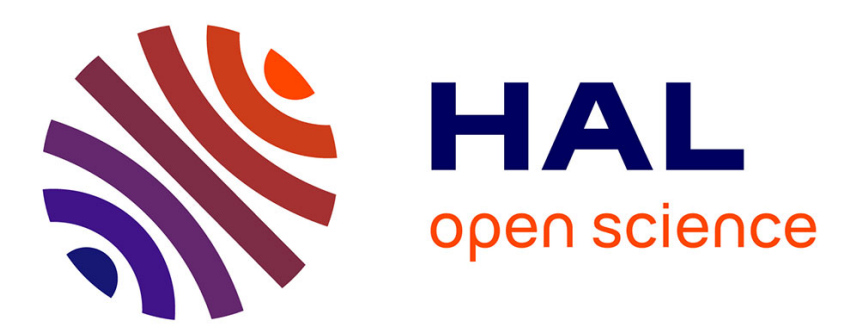

\title{
Regulating Skill Formation in Europe: German, Norwegian and Spanish Policies on Transferable Skills
}

Miguel Martínez Lucio, Sveinung Skule, Wilfried Kruse, Vera Trappmann

\section{To cite this version:}

Miguel Martínez Lucio, Sveinung Skule, Wilfried Kruse, Vera Trappmann. Regulating Skill Formation in Europe: German, Norwegian and Spanish Policies on Transferable Skills. European Journal of Industrial Relations, 2007, 13 (3), pp.323-340. 10.1177/0959680107081744 . hal-00570968

\section{HAL Id: hal-00570968 \\ https://hal.science/hal-00570968}

Submitted on 1 Mar 2011

HAL is a multi-disciplinary open access archive for the deposit and dissemination of scientific research documents, whether they are published or not. The documents may come from teaching and research institutions in France or abroad, or from public or private research centers.
L'archive ouverte pluridisciplinaire HAL, est destinée au dépôt et à la diffusion de documents scientifiques de niveau recherche, publiés ou non, émanant des établissements d'enseignement et de recherche français ou étrangers, des laboratoires publics ou privés. 


\title{
Miguel Martínez Lucio, Sveinung Skule, Wilfried Kruse and Vera Trappmann \\ University of Manchester, UK, Oslo University College, NoRWAY, Sozialforschungsstelle Dortmund and University of Jena, GERMANY
}

\section{Regulating Skill Formation in Europe: German, Norwegian and Spanish Policies on Transferable Skills}

\begin{abstract}
The article explores the new policy frameworks for learning and skills formation in Germany, Norway and Spain. It asks whether a new type of regulation for training is emerging, and how employers and trade unions engage with such developments. It ends arguing that there are competing dynamics, strategic directions and actor-related issues within these new departures in industrial relations.

KEYWORDS: lifelong learning - skills - social partners - supply-side corporatism
\end{abstract}

\section{Introduction}

Governments, employers and trade unions increasingly face a need to prepare workers for a new and more flexible labour market, and the prospect of a working life which involves a variety of occupations and skills. This article aims to show how a new politics of skill formation has emerged, facilitating and regulating the development of workers' competences and transferable skills. It examines three Western European countries, Germany, Norway and Spain, that are committed to a politically and socially inclusive response to the new economic context.

We explore the dynamics, directions and actors involved, the variety of approaches and differing points of emphasis. The article asks whether developments in the regulation of skills formation represent a robust and stable system of supply-side industrial relations. We start with a discussion of the new interest in lifelong learning and the new language of skills, then outline the various motives and strategies involved in these new departures in industrial relations. We argue that the rhetoric of such developments conceals underlying tensions related to the politics of skill formation. 


\section{The New Politics of Skill Formation}

Throughout Europe, labour is constantly being 'recycled' as traditional industries are downsized and new forms of economic activity emerge, and in recent years the pressure of change has accelerated. The emergence of the service sector as a major vehicle for employment generation has placed a strain on labour markets as shortages and gaps appear.

From Silicon Valley to Stockholm, and from England to Finland, the most important problem for leading companies has become where to find engineers, computer programmers, e-business professionals, financial analysts, or, for that matter, anyone with the capacity to develop new skills as required by a changing market. (Castells, 2001: 92-3)

There is a perceived need for greater mobility of employees across industrial sectors and different organizational environments. Within the EU, this was expressed in the Lisbon Council commitment in 2000 'to become the most competitive and dynamic knowledge-based economy in the world', making innovations in training and learning a major driving force in public policy. The assumption that the new economy brings a need for new forms of skills and competences is virtually unquestioned, and is linked to an emphasis on 'soft', transferable skills, the validation of non-formal and informal learning, and access to learning for workers with low formal skills. Thus the policy frameworks across Western European countries (and also in the New Member States and candidate countries to the east) take for granted that transferable skills and a broader, social understanding of skills are necessary for the development of a more competitive European economy and a more effective system of support for workers.

However, it is widely accepted that skills are not neutral; their recognition and classification are subject to ideological and political structuring, reflecting factors such as gender (Adkins, 1999; Heyes and Stuart, 1994). The manipulation of skills and their transformation within economic and corporate restructuring can be the subject of political interventions and become contested (Stuart, 1996). Within the EU it should not be regarded as a given that industrial relations actors will craft their way into the regulation of the new politics of skill.

\section{Roads to a New Politics of Skills}

The three national cases discussed in this article demonstrate how distinct regimes of regulation and employment relations have underpinned the move towards a new flexible form of skills. Each system represents a distinct variant of regulated systems of industrial relations. The countries 
have embarked on a strategic development of skills and learning within a context of social dialogue.

Both the German and Norwegian systems allocate labour an institutionalized role within the regulation of employment relations. In Germany, key features of regulation have been the development of clear national regulatory criteria, for example on issues of skills; the strong cultures of participation at company and workplace level; and the important functions of regional governments (Länder). Regional regulatory activity through agreements and institutions, backed up by industry-wide agreements, play a key role in vocational and general education. In recent years, the multi-employer system has begun to show signs of decentralization, giving rise to problems of coordination.

Norway possesses a highly centralized and regulated system of industrial relations with a strong legacy of labour-state-employer mediation, hence being typical of the Nordic context. This has been underpinned by a strong social-democratic consensus during much of the latter 20th century. The centrality of national and sectoral bargaining, sustained by strong employee and employer associational cultures, has permitted substantial coordinated intervention and extensive industrial relations regulation.

In Spain, the system of industrial relations is in formal terms relatively strong and shares some of the core characteristics of the first two countries. Whilst trade union membership is lower, collective bargaining coverage is relatively high: over four-fifths of the workforce is covered by a collective agreement. There is high participation in works committee elections, with most workers voting for the two main left-oriented union confederations, which are concerned to extend the regulatory role of labour in areas such as lifelong learning and the development of new skill categories. Much of the influence of trade unions has historically been external to the workplace (Ortiz, 1999), with periods of state-labour negotiation on industrial relations issues. Unions have politically embraced the discourse of lifelong learning and seen it as way of influencing employment agendas and building a workplace presence - something that has never been a central feature of Spanish union structures. Workplace representation, working conditions and even dismissals are highly regulated in legal and formal terms although there are elements of informality within the system and problems of coordination (Martínez Lucio and Stuart, 2003). National political exchange has at times been spasmodic and driven by political factors. It has been strategic and less ingrained in structural terms but has evolved over time (Martínez Lucio, 2002).

All three countries are exposed to the same pressures of change in terms of labour markets and the emergence of new sectors and forms of competition, although they start from very different positions. This is an issue at the heart of EU concerns regarding productivity and change (Greenwood and Stuart, 2006), even in Norway, which is not in the EU. 
However, they are engaging and framing this challenge in different ways because of the institutional contours of their industrial relations systems and their legacies of skills.

\section{Motives for Change}

The German model is one of the most regulated and effective in terms of training, but has faced the dual pressure of fine-tuning this system to reflect the changing nature of skills, and confronting the problem that a growing proportion of the population is excluded from it. Inclusion and regeneration are underpinned by a dual desire to sustain a competitive edge through workforce skill levels, and also by the increasing challenge of restructuring and a growing pool of disconnected and unemployed workers. Regional disparities following unification have also fuelled pressures for change. Efforts to reform the training system have necessitated a dialogue about the system itself.

In Norway, attention to lifelong learning and new forms of skills development has been driven by the unions, which fear a two-class hierarchy emerging within the workforce (Teige, 2006): restructuring threatens workers without formal education with exclusion from the labour market. Adult education and lifelong learning came to the forefront of the political and collective bargaining agendas from the late 1980s. Trade unions and employers began to lead on this issue because of the social and economic problems they perceived, with the state supporting what was in the beginning a bipartite initiative. The leading force behind this was LO (Landsorganisasjonen i Norge), the largest trade union confederation. Against a backdrop of economic recession and rapid changes in the labour market, at its 1993 congress LO identified further and continuing education for the workforce as one of its prime objectives. One of the main arguments was the danger that new class differences would emerge, as LO saw that many of their members with little or no education were increasingly being excluded from the labour market. Following the congress, LO and NHO (Nxringslivets Hovedorganisasjon, the Confederation of Norwegian Enterprise) agreed to modernize competence development. Their joint declaration insisted 'how highly important further education is for the individual, for development of the enterprise, and for the community as a whole' and established further and continuing education as a joint responsibility of employers and employees (Skule, 2004). It is generally accepted that the Norwegian model of skills regulation is ahead of many European counterparts (Payne and Keep, 2005).

Spain has had to develop rapidly the skills and educational basis of its workforce, given its uneven development and the challenges of European integration and insertion into global capitalism. It was only in 1996 that 
the majority of citizens of working age had completed what was then the school qualification relevant to 14-year-olds, while over half the population aged over 45 had not received any type of qualification even at primary level (Homs, 1999). The situation has been changing but this statistic, not too dissimilar to some other Mediterranean countries, highlights the context of the emergence of a lifelong learning debate. This group would have constituted the mainstay of the working class during the economic miracle of the late 1960s and 1970s. However, the rapid changes in Spanish education become apparent when one considers that the figures for workers aged 16-24 without a qualification of any sort has been rapidly falling in the past 20 years. This reflects the corresponding increase in the role of the state in education in the same period. In effect, whilst there have been improvements we see a dual workforce emerging with a younger and more dynamic group having very little in common with their older counterparts; this could be argued to be the case in many countries but is especially acute in Spain.

\section{Changing Skill Regulation}

All three countries have recently had a spate of national agreements and policy developments in the area of learning. They have been driven by both common and nationally specific concerns regarding productivity and social inclusion, yet in all cases new interventions have been underpinned by social dialogue at various levels of the industrial relations system. The routes to a new system of accredited skills and systems of training that recognize the broader remit of worker activity are such that there have been different actors and regulatory 'levers' present in the re-crafting of skill. The implementation of regulations remains locked in particular national and even local contexts. The three cases are discussed with an initial presentation of recent Norwegian initiatives, which have been seen as the EU benchmark for many of the developments under discussion.

\section{Initiatives in New Learning Arrangements}

In Norway, a high-level Forum for Competence Building, led by the Minister of Education, and comprising representatives of the social partners and education providers, was appointed in 1999. A reference group made up of specialists from the same member organizations met monthly to coordinate the implementation of the reform. These groups formulated an action plan for the Competence Reform for 2000-03, and the Ministry of Education took on the responsibility for implementation. LO and $\mathrm{NHO}$ set up a joint secretariat to implement the reform within their own jurisdiction. 
The social partners strongly influenced the content and priorities of the Realkompetanse project that was set up to develop a national system for validating non-formal and informal learning. From the start its mandate was validation through the educational system, for those who wanted to enrol in educational institutions. The social partners used their influence to extend this mandate to the development of validation tools for working life, directed at skills development and human resource management in enterprises and mobility in the labour market, and targeting even employees that do not intend to enrol in formal education programmes. This approach became a major benchmark for the EU, even though Norway is not a member.

While the issue of financing living expenses during educational leave remained unresolved throughout several bargaining rounds and the work of public tripartite committees, this interaction between the social partners and the public authorities resulted in a framework of statutory rights, arrangements and development programmes. First, statutory rights have been introduced for adults to primary education (from autumn 2002) and upper secondary education (from autumn 2000). Second, a statutory right to study leave for up to three years has been integrated into the Work Environment Act (from 2001). Third, tax regulations have been changed to exempt employees from paying income tax on most employer-paid education. Also student loans have become more readily available for adults who work parttime. Fourth, a legislative amendment obliges universities and colleges to assess adult applicants who apply on the basis of documented non-formal learning (from 2001). Similar rights have been provided at upper secondary level, and all counties have established centres for validating informal learning. Finally, the Competence Development Programme that emanated from the 1999 bargaining round has supported some 700 local projects all over the country to develop education and training programmes that are tailored to the needs of companies and employees. The programme is built on a partnership philosophy. It has a board of executives consisting of representatives of all the main trade unions and employer federations. In order to receive support from the programme, applicants have to demonstrate a partnership agreement between the employers and employees, as well as between enterprises and providers of education and training.

The type of interaction referred to above is part of the broader Norwegian model of policy formation, which as noted above is marked by a high degree of centralization, although vocational education and training have a regional dimension. The centralized system of collective bargaining enables the social partners to act in concert with the government, which is often drawn explicitly into the bargaining process through joint demands from the social partners. There is also a strong tradition for governments to involve the social partners in public commissions and in social and legislative reforms. 
The main problem however is the need to raise interest in these issues at the local workplace level. Case studies of the Norwegian shipbuilding industry (Teige, 2006) demonstrate how local unions, even after years of crisis and downsizing, fail to develop an active learning strategy to increase their members' employability. Training is seen as the employers' responsibility, and employers have difficulties engaging union representatives to take an active part in bipartite training committees. A $2003 \mathrm{LO}$ survey concluded that there was a lack of motivation and knowledge amongst local representatives (Skule, 2004), and it is felt that regional governments do not allocate sufficient resources to providing adults with upper secondary education tailored to their needs (Haugerud et al., 2004). Employers seem to be the driving force for organized learning at the local level, since local trade union representatives are not very proactive in this policy domain. Hence there are a range of challenges regarding implementation and creating the material and ideological basis for an active engagement with learning developments (Skule et al., 2002).

In Germany, codetermination in the field of education and vocational training is guaranteed at two levels: directly at company level (works councils are involved in defining curricula for vocational training) and indirectly through the participation of the social partners at national level. The German vocational training 'dual system' is particularly stable because it is embedded in German industrial relations and closely linked to the companies. At national level, codetermination is realized through the representation of trade unions in the BiBB (Federal Institute for Vocational Training, Bundesinstitut für Berufsbildung). The trade unions, employers' associations, federal government and Länder each hold a quarter of the seats on its governing body, which operates by consensus, with unions exercising considerable influence. The research carried out by the $\mathrm{BiBB}$ often shapes decisions in developing or reforming job profiles. Although participation of the social partners in developing and designing training regulation does not have a legal foundation, the state always recognizes the principles of agreements, so that in reality the unions and employers' associations define the content of vocational training to a very large extent. There are other joint initiatives such as creating jobs and training initiatives for young people; regional vocational training conferences; qualification initiatives which promote job rotation; and collective agreements for lifelong learning. In some regions, the negotiators in the metal industry have agreed to external management of vocational training in SMEs.

Participation within the vocational training system is based on formal and informal arrangements. At the company level, codetermination is established by law. Although the legal definition of training includes both initial training and continued vocational training, in the past works councils concentrated on the former. Only recently has a stronger commitment 
to further education and continued vocational training evolved. Formal trade union rights to shape vocational training include advice on equipping company-based training centres, and the introduction of companybased training and participation processes in regional vocational training. The employer is obliged to inform the works council about training, and both employers and works councils are obliged to promote vocational training. Besides these legal rights, there also exist informal arrangements for works councils. One big challenge is to increase the number of vocational training places. Trade unions have begun to try to coordinate their influence at company, regional and national level.

A high level of trust among the social partners characterizes local agreements, even though these are often the outcome of fierce conflict (Trappmann and Kruse, 2002). The most far-reaching example is the collective agreement in metal-working in Baden-Württemberg (Qualifizierungstarifvertrag) in 2001. Training is guaranteed and certificated. A regular meeting between the employee and the employer evaluates the need for training and qualification. The employer covers all costs: time spent in training counts as working time, and is therefore paid, as is the time needed for travelling to an external training institution. An employee wishing to obtain individual further training may also take unpaid educational leave with a guarantee of reemployment, or may switch to part-time work in order to combine further education and employment. Particularly interesting is the joint creation of an agency for the promotion of continued vocational training.

The main challenge of such reforms is their limited reach. In the case of continuing vocational training, only those in the specific region and sector enjoy the benefits described above. Most training programmes are run by private enterprises and agencies of the public labour offices, and continuing vocational training is still only lightly regulated in Germany. Lifelong learning is a fairly new approach and up to now is not heavily regulated, but pilot projects are common especially at the regional level. In general lifelong learning, when it is located outside the workplace, has very little or no input from works councils. But when it comes to an activity run by the enterprise and/or where an employee has a right to participate, then the works council has participation rights. Clearly, what is beginning to challenge the system is that whilst trade unions and employers' associations have a deep role in training regulation, its breadth and coverage is being challenged by the new demands resulting from social exclusion and the need for flexibility.

In Spain, training and development have been the focus of dedicated institutional strategies and concerted reform during the last decade. The social costs of extensive industrial restructuring during the 1980s and 1990s, high levels of unemployment, severe problems of labour market access and labour market flexibility for younger and female workforce (and a new immigrant workforce), and the continuing legacies of underinvestment in 
basic educational skills all combined in the 1990s to give an impetus to a strategy for lifelong learning. In the 1980s a range of pacts between unions, employers and government engaged with the reform of training and set broad objectives for the adoption of lifelong learning. However, a bipartite agreement between unions and employers in 1992 showed that both sides of the employment relation were committed to reform, drawing the government into a tripartite agreement a few months later that combined state resources with a new levy on employers, half of which is spent on lifelong learning (Sánchez Reinón, 2001). Political investment in lifelong learning has been accompanied by a series of regulatory and research networks. Lifelong learning initiatives that are eligible for funding are both company- and sector-based, and training plans have to be agreed by works committees. The joint management of training and the pivotal role of sector level collective agreements in articulating training needs and strategy is now quite common, with negotiation over accreditation since 1996 (EIRO, 1998).

The new tripartite approach resulted in the Fundación Tripartita para la Formación en el Empleo (FORCEM), with an annual budget to administer the policies. Subsequent national agreements have enhanced the funding for lifelong learning and strengthened the institutional role of the key actors. The Third Tripartite Agreement on Continuous Training aimed to reform FORCEM with a more proactive role for the state, and provided a greater role for smaller and company-based applications (Martínez Lucio and Stuart, 2003; Sánchez Reinón, 2001).

One of the concerns that emerged in the 1990s was that whilst the number of both unemployed and employed being trained was increasing (Consejo Economico y Social, 1998), the social partners were inconsistent in applying, administering and supporting lifelong learning. It seemed that unions were engaged mainly for the recruitment possibilities (Rigby, 2002). Nevertheless, unions also see an opportunity to modify management strategies within the workplace and to redefine the issue of flexibility and move it towards a more qualitative agenda. In some cases they have even acted as agents for smaller businesses and enterprises, organizing bids for funding and training programmes (Rigby, 2002).

At national level, this corresponds to a new institutional role that has been historically denied them. The political and national exchanges around skill appear to be more stable than on such issues as health and safety and employment contract regulation. However, changes are emerging in the regulation and financing of projects. The role of the state and the development of FORCEM into the Fundacion Tripartita para la Formacion Continua in 2001 has meant that the financing of training projects is more rigorous. Employers can now have their social security/ national insurance payments reduced if they develop specific training and learning programmes. There has also been political discrepancy over 
lifelong learning and its administration between the central and regional states. In this respect, the politics of lifelong learning and the inclusion of social actors in Spain are more delicate and contentious than in the previous two national cases discussed. So whilst successive governments have made much political capital by developing lifelong learning, the mechanics of its regulation remain subject to ongoing scrutiny.

In all three countries there are significant developments in the role of lifelong learning. A broader approach is being taken with a significant input from trade unions and employers. Yet the establishment of a system of training regulation entails the development of structures and strategies at myriad levels. Table 1 indicates some of this diversity.

\section{Initiatives in Rethinking Skill}

'Validation of non-formal and informal learning has become one of the important building blocks in promoting lifelong learning in Europe, and in encouraging and facilitating access to learning for groups with low formal skills' (Skule and Ure, 2004). The development of a lifelong learning strategy calls into question how we traditionally view skill and competences. The delivery and regulation of new forms of training require the construction of a new language of training and skill.

TABLE 1. Organization and Challenges of New Skills Formation and Lifelong Learning (LLL) in Germany, Norway and Spain

\begin{tabular}{|c|c|c|c|c|}
\hline & $\begin{array}{l}\text { Concertation } \\
\text { system }\end{array}$ & $\begin{array}{l}\text { Agenda } \\
\text { setting in } \\
\text { LLL }\end{array}$ & $\begin{array}{c}\text { Character of } \\
\text { industrial relations }\end{array}$ & $\begin{array}{l}\text { Challenges for } \\
\text { regulation }\end{array}$ \\
\hline Germany & $\mathrm{Bi}$-/tripartite & $\begin{array}{l}\text { Social } \\
\text { partners } \\
\text { lead }\end{array}$ & $\begin{array}{l}\text { Close cooperation } \\
\text { at national level }\end{array}$ & $\begin{array}{l}\text { Works council can } \\
\text { influence work- } \\
\text { place LLL but } \\
\text { no role outside } \\
\text { Unions chal- } \\
\text { lenged because } \\
\text { of the limited } \\
\text { coverage of LLL } \\
\text { agreements }\end{array}$ \\
\hline Norway & Tripartite & $\begin{array}{l}\text { Social } \\
\text { partners } \\
\text { initiate }\end{array}$ & $\begin{array}{l}\text { Close cooperation } \\
\text { at national level }\end{array}$ & $\begin{array}{l}\text { Relative union } \\
\text { weakness at } \\
\text { workplace level }\end{array}$ \\
\hline Spain & Tripartite & $\begin{array}{l}\text { Increasingly } \\
\text { state-led }\end{array}$ & $\begin{array}{l}\text { Weak social } \\
\text { partners, } \\
\text { cooperation } \\
\text { under stress }\end{array}$ & $\begin{array}{l}\text { Low union } \\
\text { capacity, state } \\
\text { structure, } \\
\text { fragmented } \\
\text { employers }\end{array}$ \\
\hline
\end{tabular}


In all three countries, national systems of regulation have had to accommodate a more flexible and inclusive understanding of competence and knowledge, and this has presented a major institutional and economic challenge (Delamare-Le Deist and Winterton, 2005). Though all the countries have developed projects at the macro- and micro-levels to allow for broader approaches the most systematic approach has been in Norway. Here, though $\mathrm{NHO}$ was a partner in the project it was rather sceptical towards the development of new validation tools; the main fear was that employees who had their non-formal and informal competencies validated would demand a wage premium. However, a number of different tools for validating non-formal and informal competencies have been developed. Most start with some sort of self-assessment, which is then subject to discussion, evaluation and ultimately validation, and signed by the employer. An experiment in using this kind of work-based competence passport as a starting point for validation in the education system showed that differences persist between how prior learning is valued in working life and in school. One important difference was that employers are primarily interested in recording what the individual can actually accomplish in relation to tasks in the enterprise, while the point of departure for education providers is to map competencies against a given curriculum or plan of study. Translating the competence passport issued in working life into the scheme used by the upper secondary education was thus necessary (Skule and Ure, 2004). While some of the tools developed in working life received favourable evaluations from human resource managers as well as from employees who took part in these experiments (Skule and Andersen, 2001), the diffusion of the tools throughout working life has so far been limited. Several factors may contribute to this failure. One is that workers may be sceptical about how the documentation might be used by the employers in times of downsizing. All in all, neither unions nor employers appear to have a sufficiently strong interest in propelling this work forward.

In the other two countries there are similar developments and commitments but they are at an earlier stage. In Germany, there is a systematic attempt to develop a framework for classifying new forms of skills and competences. At sectoral level, trade unions and employers have on occasions developed a variety of agreements to revise definitions of skill, and there are also many pre-agreements on aims and procedures. The question of undocumented skills and prior learning is new for Germany; new legislation is providing some openings with pilot agreements being developed at enterprise level. There is a shift in emphasis from qualification to competence, with new licences of a 'bottom-up' nature driven mainly by companies and further education institutes. How they connect to formal qualifications is the next main challenge; much may depend on broader changes in German industrial relations, with declining coverage of trade unions and works councils. 
In Spain, the sheer scale of the rethinking of formal qualifications, skill classifications and competences presents a major challenge to a system of sectoral regulation that varies in scope and capacity across sectors and regions. There have been attempts to rationalize, reduce and link the different occupations. Legislation in 2004 has provided a framework for sectoral bargaining over a new set of occupational classifications and related competences; revisions to 80 out of 940 vocational qualifications had already been agreed by early 2005 . The challenge is to create a coherent and relevant link between academic, professional and vocational/lifelong learning, when regional structures vary according to the role and capacity of organized employers and unions; some regions have been able to underpin these national developments with a proactive training strategy whilst others have lagged behind. Immigration - a new phenomenon in Spain - has also raised a need to consider competence and qualifications on a broader scale, yet the social partners have been unable to link the changing national systems into the new expectations and skills portfolios of migrants.

This aspect of regulation has been less developed in relation to skills strategies in the three cases, even if Norway shows high levels of political commitment. Within the EU the object is to provide a link between higher education, vocational education and training, school education and adult/ lifelong learning. There have been tentative attempts to re-classify the language of skills, to acknowledge broader views of skills and to enhance the body of abilities within the workforce in particular. There is an irony: the new economy needs a synchronized system of regulation just as that system of regulation is challenged by the broader macro-level policies of the state. It is to these issues we now turn.

\section{Discussion: The Dynamics, Directions and Actors in the Regulation of Skill Formation}

The transformation of the regulation and meaning of skill has involved organized labour and employers' associations as collective expressions of social interests in a novel and interesting way. The move to the 'new economy' does not in this case preclude the role of traditional social movements. The experiences of lifelong learning and training outlined above still have industrial relations actors and institutions articulating their development. However, there are various challenges facing the new regulation of skills, three of which are discussed later.

\section{Dynamics}

In terms of motives we see that there are tensions in the development of learning strategies. Such developments represent the basis for a new form 
of meaningful work and existence; a social set of agendas within employment. However, they also represent a greater degree of productive potential and flexibility for human behaviour at work, and this may facilitate new forms of exploitation and labour malleability (Stewart, 2004). Those embarking on the road to a new flexible and enlightened regime of work are confronted by potentially contradictory discourses and concerns.

There are four dimensions to this problem. In all three countries, there are problems of political and institutional coordination between the two faces of the new training: the re-classification and flexibilization processes, on the one hand, and lifelong learning investment and initiatives, on the other. Linking these two is a major organizational and regulatory challenge. The second dimension is the role of the sectoral level of industrial relations. The extent and effectiveness of such a level of regulation varies between sectors and across countries; and in Europe there is uncertainty amongst policy-makers and policy communities as to whether the nationstate or the sectoral dimension should be the main platform for executing new forms of EU regulation and convergence. At a time of decentralization and individualization the role and reach of such levels of bargaining and activity are questionable, but this is the main space for providing relevant frameworks for the changes discussed in this article. The third dimension is the relation between macro- and micro-levels of the economy, and the extent to which trade unionism at local level of and SMEs let alone local public agencies - can actually implement and effectively participate in such changes. SMEs are a universal challenge for trade unions. Finally, there is a need for synergy in the objectives and aspirations of the main actors - and not just collective ones. The link to the individual and the development of a broad vision of learning, which is not just technical and economic but also social and imaginative, is important (Trappmann and Kruse, 2002). It is doubtful whether such a degree of congruence is ever achievable, since neo-corporatist systems are sustained by multiple, ongoing and diverse political exchanges and developments (Marin, 1990). Systems may be adaptive and engage with new economic objectives in a variety of ways. Yet the challenge of a new regime of learning and skill is one that will test the new systems of the state and civil society in curious ways.

\section{Directions}

The direction taken by the actors also vary. Employers in all three countries have embarked on the journey of lifelong learning, but with a specific view of their own needs; a technical desire for a multi-skilled, polyvalent, malleable and flexible workforce drives their interest. The social dimension in terms of soft skills, personal confidence and individual knowledge is important to the extent that it yields economic benefits. The range of 
incentives provided to employers has led to a new regime and industry of learning. However, this regime is not as multi-dimensional, social, and linked into broader learning criteria as trade unions have at times desired.

Technical and vocational expertise is generally certified by professional bodies, educationalists or experienced and expert workers (Abbott, 1998; Friedson, 1988, 1994). Soft skills, in marked contrast, are defined by the employer who also specifies how they should be demonstrated and the means by which they should be assessed (Grugulis, 2006). And in the case of Spain, Carvajal Muñoz (2002) has pointed to the role of courses for the unemployed which develop soft skills as a mechanism of social control.

It is widely recognized that learning in isolation cannot sustain a new competitiveness. In Germany, where wages are closely bound by collective agreements, some argue that only innovation in production can increase the demand for labour (Müller, 2001; Trappmann and Kruse, 2002). So the social partners may need to lobby over investment and industrial development, and not just focus on learning in isolation.

Another problem is that organized labour varies in terms of its interests. Unions in all three countries see lifelong learning and training as a platform for enriching workers' lives and the development of a more meaningful, dignified and recognized form of labouring. In addition, training is seen as a platform for trade union renewal. Trade unions can continue to tunnel their way into the regulation of work and into the relevance of working people's lives, especially in a context of extensive social and political change. In all three countries it appears that labour has a greater interest at the political level in such developments.

Also problematic is the question of internal governance. Within organized labour there are varying degrees of interest and capacity for acting on skills and learning issues. Even the Norwegian case study found empirical evidence that local trade unions were less advanced in their interests because of a range of constraints, some of which may indeed be structural as we will explain below.

\section{Actors}

Even where organized labour takes a greater political interest than capital, there are still issues of capacity and resources. The new language and practice of skill require a highly coordinated set of strategies on the part of social actors, public institutions and firms. This requires the ability not just to negotiate change, but to manage, implement and network, within an increasingly decentralized context of industrial relations. In Germany and Spain, trade unions have recruitment problems and face serious issues with the age profiles of their organizational leadership, regardless of renewal policies and targeted inclusion of young, female and ethnic minority members. And on occasions, in all three countries pressures 
associated with organizational restructuring accentuate problems of implementation and obstruct the willingness of trade unions and employees to participate in lifelong learning. In Norway, Skule (2004) argues that in industries such as shipbuilding, traditions of not being involved in training lead to a situation where the employer is seen as being the one who is responsible for developing strategies and resources. There is also a lack of knowledge regarding lifelong learning and its purpose, which should not be surprising given that training has rarely been included at local levels and that the sheer complexity and suddenness of the debate calls into question the capacity of local trade unions and management. That is not to say there is no engagement at the regional and workplace levels, it is a question of supporting the infrastructure of negotiation and training that the new system in all three countries requires.

Employers also have a capacity problem, especially SMEs and associations. Rigby (1999) has shown how the management limitations and low administrative resources of SMEs have led in some instances to trade unions approaching them as marketers and organizers of lifelong learning and re-training programmes funded by the state. The new industrial relations of training forces new issues of capacity, resourcing and strategy to the forefront of industrial relations: this is an issue not lost on the EU whose programmes have addressed the need to build up industrial relations capacity'. The new economy and the new regulation require new skills and new approaches, let alone new identities.

\section{Conclusion: A New Supply-side Corporatism?}

The regulation of skills is being reorganized throughout Europe, and the language and practices of industrial relations shift in response to these new interests and demands. Yet whether we are seeing a new regime of skill formation is still questionable. A new discourse of skills is emerging, along with shifts in the way workers are trained and re-trained; but the nature of such shifts and the underlying political processes are complex. The main issue is how to deal with such developments in a context of further fragmentation and localization of industrial relations. Ultimately, changes to systems and processes can alone have only limited effects, since the end user is the individual (Trappmann and Kruse, 2002). This is why it is essential to understand the dynamics, directions and actor capacity within the politics of skills.

This raises another challenge for industrial relations systems: the development of visions of education, learning and individual progress that can underpin the institutional realignments outlined above and actually engage the individual. This is a broader question of regulatory renewal (Martínez Lucio and MacKenzie, 2004). Not solely are institutions of regulation and 
their environment in need of academic and strategic analysis, this being the focus of this article, so is the meaning of the object of regulation: in this case the worker and the notion of skills, and by default the role of the worker in terms of participation. How these new directions in skills regulation link into expectations and needs requires future consideration.

Finally, the EU is approaching the issue in a very indirect manner. It emphasizes the supply-side, labour market dimension, funding learning and network processes between the different actors and national constituents with the aim of creating a culture of benchmarking with a central role for the social partners, in particular trade unions. This leaves the future of training - whether good practices are developed or not - very much at the mercy of industrial relations legacies; success depends on attempts at renewal, and in particular on the political commitment of employers, the organizational capacity of trade unions, and the consistency and thoroughness of state approaches.

\section{ACKNOWLEDGEMENTS}

All authors except Miguel Martínez Lucio are participants in the FP5 project 'Learnpartner' (HPSE-CT2001-00049). Data are drawn from this project except for those relating to Spain, which are from the lead author's independent research. We are grateful to Peter Leisink and Mark Stuart for comments, and to Peter Leisink for assistance with Table 1.

\section{REFERENCES}

Abbott, A. (1998) The Systems of Professions. Chicago, IL: University of Chicago Press.

Adkins, L. (1999) 'Community and Economy: A Retraditionalization of Gender?', Theory, Culture and Society 16(1): 119-39.

Carvajal Muñoz, R.M. (2002) 'Los cursos de formación ocupacional para desempleados en cuatro municipios de la comarca sierra sur sevillana: ¿formación para la inserción laboral o intercambio de intereses entre organizaciones participantes?' Rev. Témpora 5 (Mayo).

Castells, M. (2001) The Internet Galaxy: Reflections on the Internet, Business and Society. Oxford: Oxford University Press.

Commission of the European Communities (2001) 'Making a European Area of Lifelong Learning', Communication from the Commission, COM (2001) 678 (final), Brussels.

Consejo Economico y Social (1998) Memoria Anual Madrid: CES

Delamare-Le Deist, F. and Winterton, J. (2005) 'What is Competence?', Human Resource Development International 8(1): 27-46.

EIRO (1998) 'Collective Bargaining on Training', Comparative Supplement, available online at: [www. eurofound.europa.eu/eiro/1998/04/word/ es 9801220 s.doc].

Freidson, E. (1988) Professional Powers. Chicago, IL: Chicago University Press. 
Freidson, E. (1994) Professionalism Reborn: Theory, Prophecy and Policy. Cambridge: Polity Press.

Greenwood, I. and Stuart, M. (2006) 'Employability and the "Flexible Economy": Some Considerations on the Politics and Contradictions of the European Employment Strategy', in L. Alonso and M. Martínez Lucio (eds) Employment Relations in a Changing Society, pp. 104-19. London: Palgrave. Grugulis, I. (2006) Skills, Training and Human Resource Development. London: Palgrave.

Haugerud, V., Røstad, S. and Stubbe, T. (2004) Intensjoner og realiteter. Fylkeskommunenes haindtering av voksnes rett til videregående opplaring. Oslo: Vox.

Heyes, J. and Stuart, M. (1994) 'Placing Symbols before Reality: Re-Evaluating the Low Skills Equilibrium', Personnel Review 23(5): 35-49.

Homs, O. (1999) 'La Formacíon de los Trabajadores: ¿A Mas Formacíon Mayor Cualificacíon?', in F. Miguelez and C. Prieto (eds) Las Relaciones Laborales en España. Madrid: Siglo veintiuno.

Marin, B. (1990) 'Generalised Political Exchange: Preliminary Considerations', in B. Marin (ed.) Generalised Political Exchange, pp. 37-66. Frankfurt: Campus.

Martínez Lucio, M. (2002) 'Strategic Corporatism for a "Flexible Age”? State, Capital and Labour in Spain during the 1990s', in H. Compston and S. Berger (eds) Policy Concertation and Social Partnership in Western Europe. New York: Bergren.

Martínez Lucio, M. and MacKenzie, R. (2004) “"Unstable Boundaries?” Evaluating the "New Regulation” within Employment Relations', Economy and Society 33(1): 77-97.

Martínez Lucio, M. and Stuart, M. (2003) 'Training and Development in Spain: the Politics of Modernization', International Journal of Training and Development 7(1): 67-77.

Müller, H.P. (2001) 'Tarifpolitik im reifen Produktionszyklus', Gewerkschaftliche Monatshefte 2: S. 84-93.

Ortiz, L. (1999) Convergencia o Permanencia de los Sistemas de Relaciones Laborales. Madrid: Instituto Juan March de Estudios e Investigaciones.

Payne, J. and Keep, E. (2005) 'Promoting Workplace Development: Lessons for UK Policy from Nordic Approaches to Job Redesign and the Quality of Working Life', in B. Harley, J. Hyman and P. Thompson (eds) Participation and Democracy at Work: Essays in Honour of Harvie Ramsay. London: Palgrave.

Rigby, M. (1999) 'Electronics', in M. Rigby, R. Smith and T.E. Lawlor (eds) European Trade Unions: Change and Response. London: Routledge.

Rigby, M. (2002) 'Spanish Trade Unions and the Provision of Continuous Training: Partnerships at a Distance’, Employee Relations 24(5): 500-15.

Sánchez Reinón, M. (2001) 'Third National Agreement on Continuing Training Implemented', European Foundation for the Improvement of Living and Working Conditions, available at: [http://www.eurofound.europa.eu/eiro/ 2001/09/word/es0109202fes.doc]

Skule, S. (2004) Lifelong Learning - Norwegian Experiences: The Role of the Social Partners in Developing and Implementing Lifelong Learning Policies. Fafo-paper 2004: 20. Oslo: Fafo Institute for Labour and Social Research. 
Skule, S. and Andersen, B. (2001) Dokumentasjon av realkompetanse $i$ teknologiindustrien. Evaluering av TBL og Fellesforbundets dokumentasjonsordning for arbeidslivet. Fafo-rapport 363. Oslo: Fafo. Skule, S. and Ure, B. (2004) Lifelong Learning - Norwegian Experiences: Identification and Validation of Non-formal and Informal Learning. Fafopaper 2004: 21. Oslo: Fafo Institute for Labour and Social Research.

Skule, S., Stuart, M. and Nyen, T. (2002) 'Training and Development in Norway', International Journal of Training and Development 6(4): 263-76.

Stewart, P. (2004) 'Work, Employment and Society Today', Work, Employment and Society 18(4): 653-62.

Stuart, M. (1996) 'The Industrial Relations of Training: A Reconsideration of Training Arrangements', Industrial Relations Journal 27(3): 253-66.

Teige, B. (2006) 'Development and Implementation of the Norwegian Competence Reform Program: Rhetoric and Reality', doctoral thesis, Leeds University Business School.

Trappmann, V. and Kruse, W. (2002) 'Learning in Partnership: Responding to the Restructuring of the European Steel and Metal Sector', Sozialforschungsstelle Dortmund Occasional Paper.

MIGUEL MARTíNEZ LUCIO is Professor at the Manchester Business School, University of Manchester.

ADDRESS: Manchester Business School, University of Manchester, Booth Street West, Manchester M15 6PB, UK. [e-mail: mmartinezlucio@yahoo.co.uk] SVEINUNG SKULE is Research Director at Oslo University College, Norway. ADDRESS: Oslo University College, PO Box 4, St Olavs plass, N-0130 Oslo, Norway. [e-mail: svskule@start.no]

WILFRIED KRUSE is researcher at the University of Dortmund. ADDRESS: Sozialforschungsstelle Dortmund, Zentrale Wissenschaftliche Einrichtung der Universität Dortmund, Evinger Platz 17, 44339 Dortmund, Germany. [e-mail: Kruse@sfs-dortmund.de]

VERA TRAPPMANN is researcher at the University of Jena and associate of the Sozialforschungsstelle.

ADDRESS: Friedrich-Schiller-Universität Jena, Institut für Soziologie, Carl Zeiss Straße 2, 07743 Jena, Germany. [e-mail: Vera.Trappmann@uni-jena.de] 